\title{
ASSOCIATION OF POOR SELF-PERCEIVED HEALTH WITH DEMOGRAPHIC, SOCIOECONOMIC AND LIFESTYLE FACTORS IN THE CROATIAN ADULT POPULATION
}

Ana IVIČEVIĆ UHERNIK

Croatian Institute of Public Health, Zagreb

Dunja SKOKO-POLJAK

Ministry of Health of the Republic of Croatia, Zagreb

Vlasta DEČKOVIĆ-VUKRES

Croatian Institute of Public Health, Zagreb

Melita JELAVIĆ

Andrija Štampar Teaching Institute of Public Health, Zagreb

Sandra MIHEL, Tomislav BENJAK, Vesna ŠTEFANČIĆ,

Želika DRAUŠNIK, Ranko STEVAN'OVIĆ

Croatian Institute of Public Health, Zagreb

UDK: 613.97(497.5):314

Izvorni znanstveni rad

Primljeno: 25. 1. 2018.

The aim of this study was to analyse the association of poor self-perceived health with demographic, socioeconomic and lifestyle factors using data from the European Health Interview Survey. When applying the multiple logistic regression model, two demographic (male sex, older age), all four socioeconomic (low education level, unemployed and retired, living in households with lowest income, poor social support) and only one lifestyle factor (no alcohol consumption) were revealed as associated with poor self-perceived health. The association of socioeconomic factors with self-perceived health among the adult population in Croatia is direct and not mediated exclusively through lifestyle factors.

Keywords: self-perceived health, European Health Interview Survey, socioeconomic factors, lifestyle factors

Ana Ivičević Uhernik, Croatian Institute of Public Health, 
Self-perceived health is a widely used indicator of an individual's general state of health. It is a multi-dimensional concept referring to the physical aspects of health, but also to the functional and wellbeing dimension of health as well as to the extent of adaptation and attitude towards an existing illness (Simon, De Boer, Joung, Bosma, \& Mackenbach, 2005). Today, self-perceived health is considered to be one of the most important health indicators. It represents the individual perception and evaluation of one's own health, so it is a better predictor of future health condition in some cases, even better than clinical assessment (Steptoe \& Wardle, 2017).

Self-perceived health has been included as indicator No. 33 into the Health Status chapter of European Core Health Indicators (ECHI), which is the main indicator system accepted for monitoring health in the European Union (EU). Therefore, data on self-perceived health are regularly collected and readily available for numerous European countries (European Commission, 2017a). Demographic, socioeconomic and lifestyle determinants of self-perceived health have been explored in several studies in different European countries, including international comparisons which showed significant differences among countries in both self-perceived health as well as its determinants (Babić-Banaszak, Kovačić, \& Mastilica, 2002; Jureša et al., 2000; Vuletić, 2013; Džakula, Babić Bosanac, Brborović, Vukušić Rukavina, \& Vončina, 2007).

In the Republic of Croatia, some research has been conducted in the past ten years or so, with self-health assessment considering various influences (age, sex, social and economic influences) as the basic indicator of health condition (Novak, Suzuki, \& Kawachi, 2015; Šućur \& Zrinščak, 2007; Smolić, 2017). The study conducted during the 1997-1999 period in fourteen Croatian counties showed that $20.7 \%$ of Croatian citizens evaluated their health as poor, and more often women, older respondents, those with lower educational level and lower income (Babić-Banaszak et al., 2002). According to the European Quality of Life Survey, which was conducted in Croatia in $2006,14.6 \%$ of Croatian citizens rated their health as poor, compared with $5.8 \%$ in the European Union (EU) member states which joined the EU before May 2004 (EU15) and 15.8\% in the EU member states which joined the EU in May 2004 - new member states (NMS). As expected, respondents in higher income quartiles assessed their health status as more favourable than those in lower income quartiles. However, when only respondents who rated their health as poor were taken into account, the proportion ratio between the extreme income quartiles in Croatia was twice the ratio in the EU15 and NMS, i.e. the poor in Croatia rated their health as poor more frequent- 
DRUŠ. ISTRAŽ. ZAGREB GOD. 28 (2019), BR. 2, STR. 229-248

IVIČEVIĆ UHERNIK, A. ET AL.:

ASSOCIATION OF. ly than the poor in EU countries. There were more rural than urban residents who rated their health as poor, and the ruralurban proportion ratio for those reporting poor health was much higher in Croatia than in the rest of the EU (Šućur \& Zrinščak, 2007).

Other studies also showed that self-perceived health status in Croatia is low, and monitoring patients over a period of five years has shown that the perception is getting worse. Self-perceived health status differs within Croatia, being the lowest in the East region (Vuletić, 2013).

According to Eurostat statistics from 2014, women generally perceive their health as poor or very poor more often than men. In the EU as a whole (with all 28 member states included), $11 \%$ of women and 9\% of men perceived their health as poor or very poor, but in Croatia $21.8 \%$ of women and $17.7 \%$ of men perceived their health as poor or very poor. In the EU, $54 \%$ of the population with completed lower secondary education, $70 \%$ of the population with completed upper secondary and $81 \%$ of the population with completed tertiary education perceived their health as very good or good. Croatia shows the largest gap in the share of the population reporting very good or good health between those with the highest and the lowest educational attainment levels (41 percentage points) (Eurostat, 2017). However, no studies in Croatia so far have analysed the association of lifestyle determinants, such as smoking, alcohol consumption, nutrition and social support with poor self-perceived health.

As the European Health Interview Survey (EHIS) included also data on lifestyle determinants, in this study it was possible to include them, alongside demographic and socioeconomic determinants, in the analysis and evaluate not only their association with self-perceived health, but also the way they modify the association of demographic and socioeconomic factors with self-perceived health in order to explore whether demographic and socioeconomic factors are directly connected to self-perceived health or if this relationship is to a great extent mediated by lifestyle factors. The aim of this study was to explore for the first time the association of lifestyle factors, alongside demographic and socioeconomic factors, with poor self-perceived health in the Croatian population.

\section{PARTICIPANTS AND METHODS}

\section{Sample}

This study was based on EHIS wave 2, which was conducted in Croatia in 2014 and 2015 by the Croatian Institute of Public Health in cooperation with the counties' and City of Zagreb 
DRUŠ. ISTRAŽ. ZAGREB GOD. 28 (2019), BR. 2, STR. 229-248

IVIČEVIĆ UHERNIK, A. ET AL.:

ASSOCIATION OF..

(1) TABLE 1

Sample according to sex, age, residence, marital status and education level the Ministry of Health. The survey used stratified two-stage random sampling of private households. The sampling frame was the 2011 population census. Primary sampling units were segments chosen with square root probability proportional to a number of private households in each primary sampling unit, while secondary sampling units were inhabitant dwellings selected from the primary sampling units with equal probability. The sample consisted of households living in 3,140 dwellings, out of which 2,401 households with 5,446 individuals aged 15 years and older participated in this survey in the period from April 2014 until March 2015.

Basic breakdown of the sample according to sex, age, residence, marital status and education level is shown in Table 1.

\begin{tabular}{llr}
\hline & & $\%$ \\
\hline Sex & Male & 47.3 \\
& Female & 52.7 \\
Age group (in years) & $15-24$ & 12.3 \\
& $25-34$ & 12.5 \\
& $35-44$ & 14.0 \\
& $45-54$ & 16.3 \\
& $55-64$ & 18.2 \\
Residence & $65-74$ & 14.2 \\
& $75+$ & 12.5 \\
Marital status & Thinly populated rural areas & 49.8 \\
& Intermediate density areas (towns and suburbs) & 32.7 \\
& Densely populated areas (cities) & 17.5 \\
& Never married and never in registered partnership & 24.5 \\
Education level & Married or in registered partnership & 59.6 \\
& Widowed & 12.2 \\
& Divorced & 3.7 \\
& Low (lower secondary education or less) & 27.0 \\
& Medium (upper secondary education) & 55.0 \\
& High (tertiary education) & 17.9 \\
\hline
\end{tabular}

The individual response rate was $81 \%$. Respondents were interviewed face-to-face or by telephone by trained interviewers. Proxy interviews were allowed for respondents suffering from severe impairments or absent from the household for longer periods. The percentage of proxy interviews was $6.5 \%$. However, proxy interviews were not allowed for certain questions, including the question on self-perceived health. Prior to participation in the survey, all respondents provided signed written consent for participation (for respondents younger than 18 years, consent was signed by their parent/legal guardian). In order for the results to be representative for the adult population in Croatia, all analyses were done on weighted 
data. Calibration was used to adjust weighting to the estimated Croatian population in 2014 according to age groups and sex (Croatian Institute of Public Health, 2016).

\section{Variables}

The dependent variable poor self-perceived health was defined by answers "very poor" and "poor" to the question "How is your health in general?" (the remaining possible answers were "fair", "good" and "very good"). Answers "very poor" and "poor" were pooled together as poor self-perceived health, while answers "fair", "good" and "very good" were also pooled together as the opposite category of nonpoor self-perceived health for the purpose of this analysis, thus creating a dichotomous self-perceived health variable.

Independent variables were divided into three groups: demographic, socioeconomic and lifestyle. Demographic variables included sex, ten-year age groups (15-24, 25-34, 35-44, $45-54,55-64,65-74,75+$ years), region of residence, degree of urbanisation of respondent's place of residence and legal marital status, while socioeconomic variables included education level, working status, quintile of household's income and level of social support.

All respondents were divided into six regions according to the county of residence which resemble their geographic and historical specifics: Northern (Krapina-Zagorje, Varaždin, Koprivnica-Križevci and Međimurje), Eastern (Virovitica-Podravina, Požega-Slavonija, Slavonski Brod-Posavina, Osijek-Baranja and Vukovar-Srijem), Southern (Šibenik-Knin, Split-Dalmatia, Dubrovnik-Neretva and Zadar), Western (Primorje-Gorski Kotar, Lika-Senj and Istria), Central (Zagreb County, Sisak-Moslavina, Karlovac and Bjelovar-Bilogora) and City of Zagreb.

The degree of urbanisation was classified according to the Degree of Urbanisation Classification of Local Administrative Units (DEGURBA) into three categories: cities (densely populated areas), towns and suburbs (intermediate density areas) and rural areas (thinly populated areas) (European Commission, 2017b).

Legal marital status included four categories: never married and never in registered partnership, married or in registered partnership, widowed or with registered partnership that ended with the death of a partner (not remarried or in new registered partnership) and divorced or with registered partnership that was legally dissolved (not remarried or in new registered partnership).

The educational attainment level is defined according to the International Standard Classification of Education 2011 (ISCED, 2011). Classification is designed to serve as a framework to classify educational activities as defined in programmes and 
DRUŠ. ISTRAŽ. ZAGREB GOD. 28 (2019), BR. 2, STR. 229-248

IVIČEVIĆ UHERNIK, A. ET AL.:

ASSOCIATION OF... the resulting qualifications into internationally agreed categories. ISCED 2011 differentiates nine levels of education: level 0 - No formal education or below, level 1 - Primary education, level 2 - Lower secondary education, 3 - Upper secondary education, 4 - Post-secondary but non-tertiary education, 5 - Short-cycle tertiary education; 6 - Bachelor's or equivalent level; 7 - Master's or equivalent level and 8 - Doctoral or equivalent level. Low education level included ISCED 0-2, medium included ISCED 3-4 and high included ISCED 5-8 (Bonner et al., 2017). Education level was determined according to the highest education level completed based on the International Standard Classification of Education-2011 (ISCED-2011). Adjusted to Croatian education levels, that means that low education level included those with completed primary school or less, medium education level included those with completed secondary school or other education level following primary school, and high education level included those with completed college or bachelor degree and higher.

Self-declared working status included five categories: carries out a job or profession (includes unpaid work for family business or holding, apprenticeship or paid traineeship), unemployed, pupil/student (including unpaid training or unpaid work experience), retired and other (includes permanently disabled, voluntary military service, fulfilling domestic tasks and other inactive persons).

Household income quintiles were calculated using data on household's size and composition and data on the total net monthly income of a household which were collected for each household participating in the survey. Equivalised total net monthly income of the household was calculated for each household as a ratio between total net monthly income of the household and equivalised household size (which is a sum of weights attributed to each member of the household according to the modified OECD equivalence scale: 1.0 to the first adult, 0.5 to the second and each subsequent person aged 14 and over and 0.3 to each child aged under 14). After equivalised total net monthly income of the household had been calculated for all households, conversion into household income quintile groups was done so that all the survey population was divided into equally represented five groups according to the value of equivalised total net monthly income of the household.

The Oslo Social Support Scale (OSS-3) was selected to measure social support. It includes three individual variables: standardised questions on primary support group, interest and concern shown by others and easiness of obtaining practical help (each scored 0 to 4 ) which are used to calculate social sup- 
DRUŠ. ISTRAŽ. ZAGREB GOD. 28 (2019), BR. 2, STR. 229-248

IVIČEVIĆ UHERNIK, A. ET AL.:

ASSOCIATION OF.. port score (with higher score indicating greater social support) placed into three categories: poor, intermediate and strong social support (Meltzer, 2003).

Lifestyle variables included body mass index (BMI), smoking status, fruits and vegetables intake and alcohol consumption. BMI was calculated from the self-reported height and weight. According to smoking status, respondents were divided into smokers and non-smokers. Fruits and vegetables intake included two categories: those who consume 5 or more portions of fruits and vegetables daily in line with the World Health Organisation recommendation and those who do not (World Health Organisation, 2015). According to alcohol consumption, respondents were divided into those who consume alcohol and those who do not.

\section{Statistical analysis}

Descriptive statistics (percentages) were calculated for poor self-perceived health as well as demographic, socioeconomic and lifestyle factors, including 95\% confidence intervals (CI). Logistic regression was used to evaluate the association of poor self-perceived health (dependent variable) with demographic, socioeconomic and lifestyle factors (predictor variables). The association of each predictor variable with the dependent variable was analysed through simple logistic regression (without adjustment for other predictor variables) and through the multiple logistic regression model which was prepared using backward stepwise elimination procedure: all demographic, socioeconomic and lifestyle variables were initially included in the model regardless of the statistical significance of their relation to the poor health calculated by simple logistic regression; at each step a variable with the weakest relationship to poor health was removed, until only variables significantly related to poor health $(p>0.05)$ remained in the model. As an indicator of goodness-of-fit of multiple regression model, McFadden's pseudo $\mathrm{R}^{2}$ index was used which indicated satisfactory goodness-of-fit for the final multivariate model $\left(\mathrm{R}^{2}=0.26\right)$ (McFadden, 1974; McFadden, 1979).

\section{RESULTS}

Distribution of poor self-perceived health among different demographic and socioeconomic population groups is presented in Tables 2 and 3.

The percentage of the population with poor self-perceived health in the Croatian adult population is $14.9 \%$ (13.7\% among men and $16.0 \%$ among women). It is constantly increasing from the youngest (15-24 years) to the eldest age group ( 75 years and older). According to the region, the percentage of the po- 
DRUŠ. ISTRAŽ. ZAGREB GOD. 28 (2019), BR. 2, STR. 229-248

IVIČEVIĆ UHERNIK, A. ET AL.:

ASSOCIATION OF...

(1) TABLE 2

Distribution of poor self-perceived health according to demographic variables* pulation with poor self-perceived health varies between $12.1 \%$ (City of Zagreb) and 17.5\% (Central region). The City of Zagreb and Southern region have both among men and women the lowest percentages of poor self-perceived health, while the Northern and Central regions have the highest. The prevalence of poor self-perceived health is higher among the population in rural areas, widowed persons, the population with low education level, retired persons, those living in households in the first income quintile and those with poor social support, with the same pattern of results recorded both among men and women.

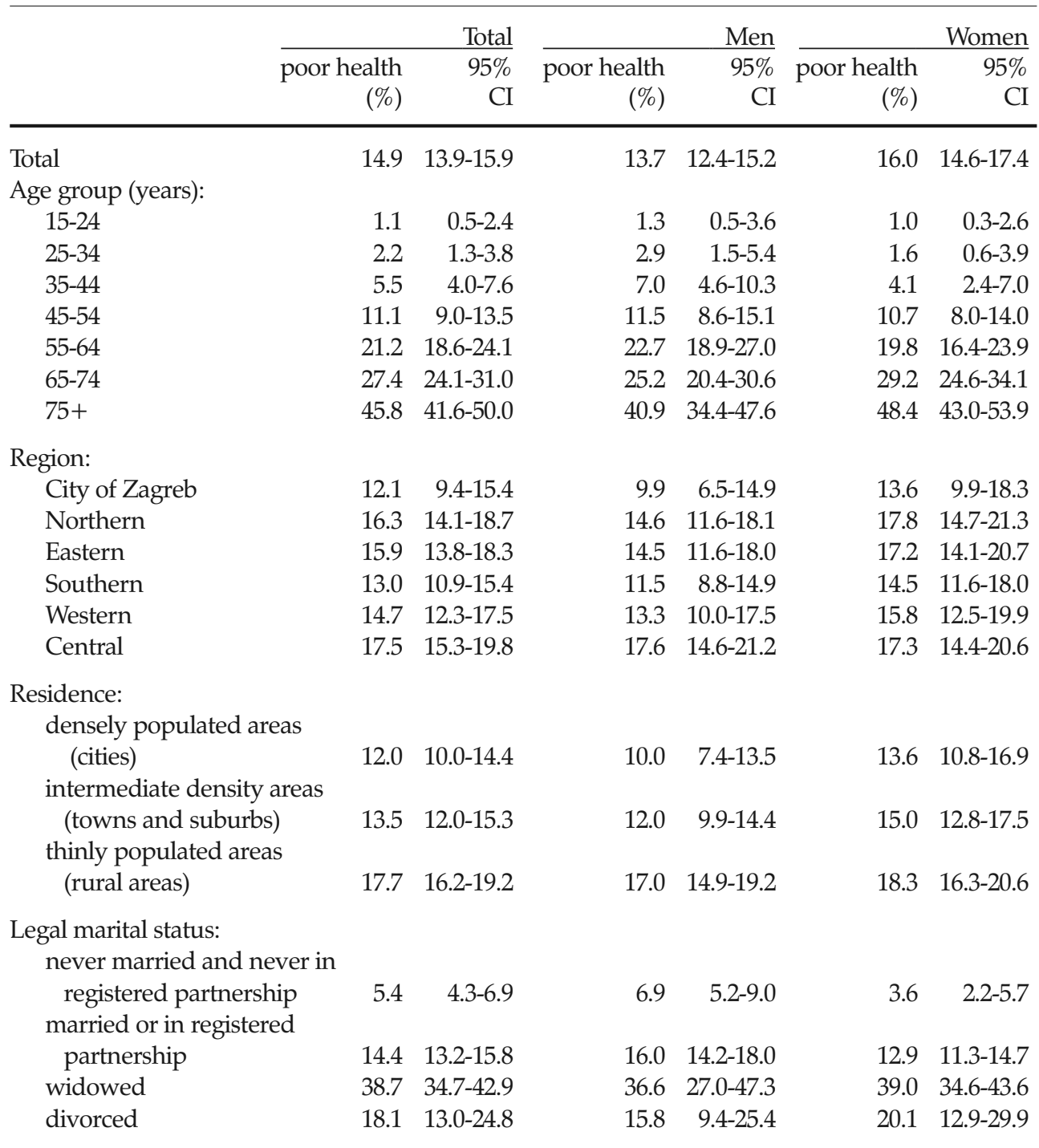

\footnotetext{
* Abbreviation: $\mathrm{CI}$ - confidence interval
} 
(1) TABLE 3

Distribution of poor self-perceived health according to socioeconomic variables*

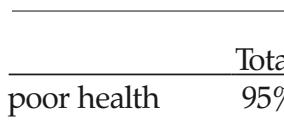

$(\%)$

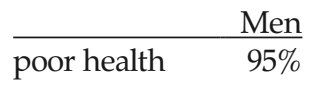

$(\%)$ poor health

Women

(\%)

\section{Education level:}

low

medium

$26.4 \quad 24.1-28.9$

$22.4 \quad 18.9-26.3$

$28.7 \quad 25.7-32.0$

high

$12.3 \quad 11.1-13.6$

$\begin{array}{ll}7.9 & 6.3-9.9\end{array}$

$12.5 \quad 10.9-14.4$

$9.3 \quad 6.9-12.6$

$12.0 \quad 10.3-14.0$

$6.7 \quad 4.7-9.4$

Working status:

carries out a job or profession $\quad 4.3 \quad 3.5-5.4$

$4.9 \quad 3.7-6.5$

$3.7 \quad 2.6-5.2$

unemployed

$11.1 \quad 9.0-13.7$

$11.4 \quad 8.4-15.3$

$10.9 \quad 8.2-14.4$

pupil/student

$0.9 \quad 0.4-2.0$

$0.7 \quad 0.2-2.9$

$1.0 \quad 0.4-2.8$

retired

$32.5 \quad 30.2-34.9$

$31.4 \quad 28.2-34.9$

$33.4 \quad 30.3-36.6$

other

$27.8 \quad 22.3-33.9$

$29.9 \quad 16.6-47.8$

$27.3 \quad 21.6-33.9$

Household income quintiles:

$\begin{array}{lrr}\text { 1st } & 22.5 & 19.5-26.0 \\ \text { 2nd } & 21.0 & 18.0-24.4 \\ \text { 3rd } & 15.2 & 12.5-18.3 \\ \text { 4th } & 10.6 & 8.5-13.1 \\ \text { 5th } & 8.0 & 6.1-10.3\end{array}$

Social support:

poor social support

$32.0 \quad 27.6-36.8$

$15.8 \quad 14.2-17.6$

moderate social support

$11.5 \quad 10.3-12.8$

$18.1 \quad 14.2-22.8$

$26.3 \quad 21.9-31.4$

$20.1 \quad 15.9-25.0$

$21.9 \quad 17.7-26.7$

$14.1 \quad 10.7-18.4$

$16.1 \quad 12.3-20.8$

$10.1 \quad 7.3-13.9$

$11.0 \quad 8.1-14.8$

$6.8 \quad 4.5-10.1$

$9.1 \quad 6.4-12.7$ strong social support

* Abbreviation: CI - confidence interval

(1) TABLE 4

Distribution of poor self-perceived health according to lifestyle variables*

BMI:

$$
\begin{aligned}
& <25 \\
& 25-29.99 \\
& >30
\end{aligned}
$$

$16.4 \quad 14.8-18.2$

$22.8 \quad 20.1-25.7$

Smoking:

smoker

non-smoker

$11.7 \quad 10.1-13.6$

$16.2 \quad 15.0-17.4$

$11.4 \quad 8.5-15.1$

$15.1 \quad 14.1-16.2$

at least 5 portions a day

less than 5 portions a day

Alcohol consumption:
yes
$10.0 \quad 8.9-11.2$
$\begin{array}{ll}10.4 & 9.0-12.0\end{array}$
$9.3 \quad 7.7-11.1$
no
$21.3 \quad 19.6-23.1$
$21.1 \quad 19.1-23.3$

$\begin{array}{rr}11.1 & 9.0-13.5 \\ 13.5 & 11.6-15.7 \\ 17.8 & 14.6-21.6\end{array}$

$11.9 \quad 9.8-14.5$

$11.5 \quad 9.1-14.4$

$14.6 \quad 12.9-16.4$

$17.5 \quad 15.9-19.2$

$14.4 \quad 9.5-20.5$

$9.5 \quad 6.2-14.3$

$16.515 .0-18.0$

$13.7 \quad 12.3-15.2$
$31.8 \quad 25.5-38.8$

$32.1 \quad 26.2-38.8$

$13.6 \quad 11.4-16.0$

$17.8 \quad 15.5-20.4$

$11.3 \quad 9.6-13.2$

\footnotetext{
* Abbreviations: CI - confidence interval, BMI - body mass index
} 
DRUŠ. ISTRAŽ. ZAGREB GOD. 28 (2019), BR. 2, STR. 229-248

IVIČEVIĆ UHERNIK, A. ET AL.:

ASSOCIATION OF...
(1) TABLE 5

Association of poor self-perceived health with demographic, socioeconomic and lifestyle variables multiple logistic regression model*
Concerning differences in lifestyle characteristics presented in Table 4, poor self-perceived health was most common among obese persons (BMI>30), non-smokers, persons who eat less than 5 portions of fruit and vegetables a day and those who do not drink alcohol. The same pattern of results was recorded both among men and women, except for eating less than 5 portions of fruit and vegetables a day, which was not related to the higher percentage of poor self-perceived health among men.

The results of unadjusted univariate logistic regression presented in Table 5 revealed that female sex (compared to male) and older age (compared to the youngest age group 15-24 years) were significantly associated with poor self-perceived health. Living in the Northern and Central regions (compared to the City of Zagreb) was significantly associated with poor health, while no significant difference was recorded for the remaining three regions. Residence in rural area (compared to residence in densely populated area - city) was significantly associated with poor health. Married, widowed and divorced had higher odds ratio (OR) for poor health compared to singles. Persons with high and middle education level had significantly lower OR for poor health compared to those with low education level. The unemployed, retired and other had higher OR for poor health compared to the employed, while pupils and students had a lower one. The OR for poor health decreased with the increase in household income quintiles. Persons with moderate and strong social support had significantly lower OR for poor health compared to those with poor social support. Both overweight (BMI 25-29.99) and obese persons (BMI>30) had higher OR for poor health compared to persons with $\mathrm{BMI}<25$. Smokers had lower OR for poor health compared to non-smokers. Eating less than 5 portions of fruits and vegetables a day was not significantly associated with poor health compared to eating at least 5 portions of fruits and vegetables a day. No alcohol consumption was significantly associated with poor health.

\begin{tabular}{|c|c|c|c|c|c|}
\hline \multicolumn{2}{|c|}{ Dependent variable: poor health } & \multirow[t]{2}{*}{ Unadjusted } & \multirow{2}{*}{\multicolumn{2}{|c|}{$\begin{array}{lr} & \text { Multivariable- } \\
95 \% \text { CI } & \text {-adjusted }\end{array}$}} & \multirow[t]{2}{*}{$95 \% \mathrm{CI}$} \\
\hline \multicolumn{2}{|c|}{ Demographic factors } & & & & \\
\hline Gender: & $\begin{array}{l}\text { Male } \\
\text { Female }\end{array}$ & $\begin{array}{l}1.00 \\
1.20\end{array}$ & $1.02-1.40$ & $\begin{array}{l}1.00 \\
0.72\end{array}$ & $0.57-0.93$ \\
\hline Age group (years): & $\begin{array}{l}15-24 \\
25-34 \\
35-44 \\
45-54 \\
55-64 \\
65-74 \\
75+\end{array}$ & $\begin{array}{r}1.00 \\
1.99 \\
5.07 \\
10.83 \\
23.45 \\
32.89 \\
73.51\end{array}$ & $\begin{array}{r}0.80-4.98 \\
2.24-11.48 \\
4.99-23.52 \\
10.96-50.19 \\
15.34-70.53 \\
34.30-157.52\end{array}$ & $\begin{array}{r}1.00 \\
0.67 \\
2.37 \\
3.90 \\
6.57 \\
6.66 \\
13.44\end{array}$ & $\begin{array}{r}0.13-3.43 \\
0.61-9.21 \\
1.04-14.61 \\
1.75-24.66 \\
1.72-25.86 \\
3.49-51.80\end{array}$ \\
\hline
\end{tabular}

(Continued) 
(Continued)

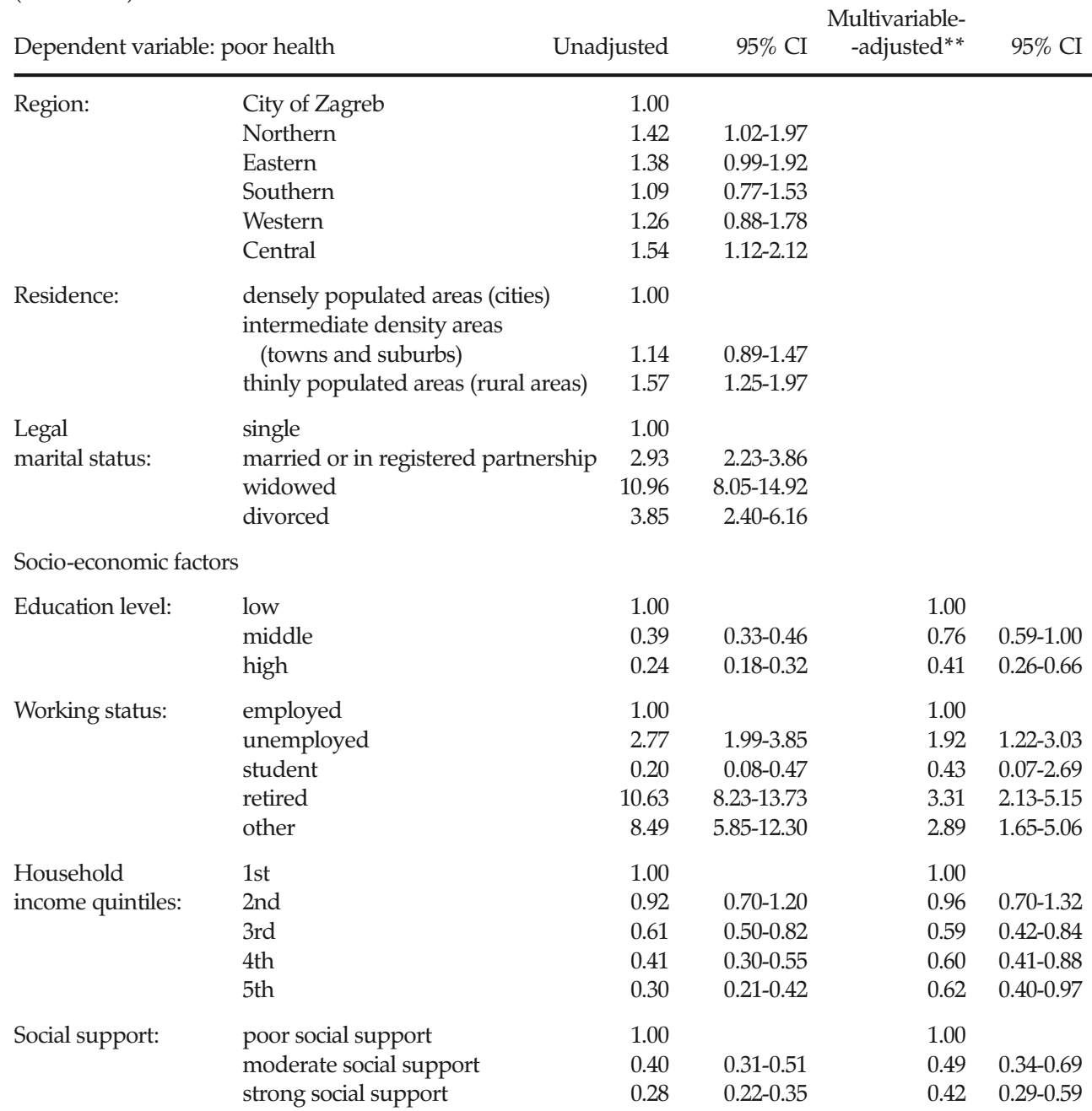

Lifestyle factors

\begin{tabular}{|c|c|c|c|c|c|}
\hline \multirow[t]{3}{*}{ BMI: } & $<25$ & 1.00 & & & \\
\hline & $25-29.99$ & 1.78 & $1.47-2.14$ & & \\
\hline & $>30$ & 2.67 & $2.15-3.30$ & & \\
\hline \multirow[t]{2}{*}{ Smoking: } & non-smoker & 1.00 & & & \\
\hline & smoker & 0.69 & $0.57-0.83$ & & \\
\hline \multirow{2}{*}{$\begin{array}{l}\text { Fruit and } \\
\text { vegetables intake: }\end{array}$} & at least 5 portions a day & 1.00 & & & \\
\hline & less than 5 portions a day & 1.38 & $0.99-1.93$ & & \\
\hline \multirow[t]{2}{*}{ Alcohol consumption: } & no & 1.00 & & 1.00 & \\
\hline & yes & 0.41 & $0.35-0.48$ & 0.49 & $0.38-0.62$ \\
\hline
\end{tabular}

* Abbreviations: CI - confidence interval, BMI - body mass index;

** backward stepwise logistic regression model was applied; initially all variables were included in the model; at each step a variable with the weakest relationship with poor health was removed (empty cells refer to such variables), until only variables significantly related to poor health remained in the model. 
DRUŠ. ISTRAŽ. ZAGREB

GOD. 28 (2019), BR. 2, STR. 229-248

IVIČEVIĆ UHERNIK, A. ET AL.:

ASSOCIATION OF...

\section{DISCUSSION}

When backward stepwise multiple logistic regression model was applied, three of the included demographic and three of the included lifestyle factors were eliminated (each in a separate step) because their relationship to poor self-perceived health was the weakest compared to other included factors and did not reach statistical significance. These factors were region, degree of urbanisation, legal marital status, BMI, smoking status and fruit and vegetable intake. None of the four socioeconomic factors were removed. The remaining seven factors (two demographic, four socioeconomic and one lifestyle factor) were kept in the final model (also presented in Table 5) because all of them were significantly associated with poor health even when controlled for all other factors included in the model. These factors were sex, age, education level, working status, household income quintile, social support and alcohol consumption. When controlled for other factors, female sex (compared to male) had lower OR for poor health. Older age (compared to the youngest age group 15-24 years) remained significantly associated with poor health. Persons with high education level retained significantly lower OR for poor health compared to those with low education level, even after adjustment for other factors. Unemployed, retired and other also retained higher OR for poor health compared to the employed. Persons in the 3rd, 4th and 5th household income quintile retained lower OR for poor health compared to persons in the 1st household income quintile. Persons with moderate and strong social support had lower OR for poor health compared to those with low social support. Out of the included lifestyle factors, only one remained significantly associated with poor health after adjustment: persons who reported alcohol consumption still had lower OR for poor health compared to those who do not consume alcohol.

According to the available information, this is the first study in Croatia which included lifestyle factors alongside demographic and socioeconomic factors in the analysis of their association with self-perceived health. The multiple logistic regression model enabled the exploration whether the association of poor self-perceived health with certain demographic and socioeconomic factors could be modified and explained by lifestyle factors. Results revealed that all four analysed socioeconomic factors were significantly associated with poor self-perceived health, not only in a univariate model, but also in a multivariable model controlled for demographic and lifestyle factors, suggesting that their association with poor self-perceived health is not mediated by demographic and lifestyle factors included in this analysis. This conclusion is 
DRUŠ, ISTRAŽ ZAGREB GOD. 28 (2019), BR. 2, STR. 229-248

IVIČEVIĆ UHERNIK, A. ET AL.:

ASSOCIATION OF. confirmed by results of studies in other populations (Kraja, Kraja, Cakerri, \& Burazeri, 2016; Janković, Janević, \& Von dem Knesebeck, 2012). Similar findings were in line with some studies suggesting that self-perceived social status was related to self-rated health and irrespective of sex, self-perceived social status was related to self-rated health, depression, and long-standing illness or disability over and above education, occupational status, wealth, age, and marital status (Franzini \& Fernandez-Esquer, 2006; Hu, Adler, Goldman, Weinstein, \& Seeman, 2005; Ostrove, Feldman, \& Adler, 1999; Singh-Manoux, Marmot, \& Adler, 2005).

Results showed that the percentage of the Croatian population which perceived their health as poor is almost exactly the same as it was in 2003, which was 14.6\% (Šućur \& Zrinščak, 2007). One of the possible reasons why respondents did not perceive the improvement of their health is the result of the downward trend of some social and economic indicators recorded in that period. Following the world economic crisis, Croatia faced a deep economic and financial crisis in a relatively long period from 2008 to 2015, which led to a significant slowdown in international trade, fall in GDP and industrial production and deterioration in numerous social and economic indicators consecutively leading to the rise of unemployment and economic insecurity and therefore contributing to the absence of improvement in overall self-perceived health status among the population in Croatia.

Compared to other European countries, the percentage of the Croatian population perceiving their health as poor is higher than in most of them. The lowest percentages of adult population with poor self-perceived health were recorded in Malta $(3.6 \%)$ and Sweden (3.8\%), and the highest, besides Croatia, in Portugal (18.0\%) and Lithuania (17.7\%) (Eurostat, 2017). The EU-SILC study also collected data on self-perceived health in Croatia and recorded an even higher percentage of the population which rated their health as poor (19.9\%), thus confirming that Croatia is among the leading European countries in the percentage of people with poor self-perceived health (Eurostat, 2017). Findings concerning the association of demographic, socioeconomic and lifestyle factors with poor self-perceived health were in general consistent with the results of previous studies.

Female sex significantly increased the chances of poor health compared to male sex in the univariate analysis, but in the multivariate model this was reversed - female sex was associated with decreased chances of poor health, meaning that the results of the univariate analysis were influenced by other factors which were eliminated in the multivariate model. That enabled the protective influence of female sex to be re- 
DRUŠ. ISTRAŽ. ZAGREB GOD. 28 (2019), BR. 2, STR. 229-248

IVIČEVIĆ UHERNIK, A. ET AL.:

ASSOCIATION OF... vealed. Although there were studies which recorded higher OR of poor health among women even when controlled for certain socioeconomic factors (Darviri, Artemiadis, Tigani, \& Alexopoulos, 2011), some of the studies obtained the same results as this: when controlled for other factors, female sex was associated with lower chances of reporting poor health (Kraja et al., 2016; Crimmins, Jung Ki, \& Solé-Auró, 2011).

As expected, age was strongly associated with poor self-perceived health both in the univariate and multivariate analyses. This was in line with a significant number of other studies, although some studies showed no association between age and self-perceived health or even the opposite effect of the age (Bonner et al., 2017; Menec \& Nowicki, 2014; Jerez-Roig et al., 2016; Janković \& Simić, 2012).

Regions were not significantly associated with differences in poor health in the multivariate model, although in the univariate analysis the Northern and Central regions had greater OR for poor health compared to the City of Zagreb. However, these differences were not significant in the multivariate model indicating that they were recorded due to differences among regions in other factors which were controlled for in the multivariate model.

The same was true for rural residence and legal marital status which did not turn out to be significantly associated with poor health in the multivariate model (Kraja et al., 2016; Menec \& Nowicki, 2014; Janković \& Simić, 2012; Pickett et al., 2015).

In contrast to demographic factors, all four socioeconomic factors remained significantly associated with poor health in the multivariate model. As confirmed in numerous previous studies, people with high education had significantly better self-perceived health compared to those with low education, even when controlled for not only demographic, but also for several lifestyle factors, suggesting that the positive influence of education on health is not achieved and cannot be explained exclusively through healthier lifestyle (Janković et al., 2012; Kurtinová, 2015).

Being unemployed as well as any other working status except being a student was associated with poorer health compared to being employed, both in the univariate model and multivariate model, which is in line with the previous studies (Janković et al., 2012). As this is a cross-sectional study, it was not possible to determine to what extent this was due to the fact that persons with poorer health are less likely to be employed and to what extent due to the fact that the unemployed experience difficult social as well as psychological circumstances. 
DRUŠ. ISTRAŽ. ZAGREB GOD. 28 (2019), BR. 2, STR. 229-248

IVIČEVIĆ UHERNIK, A. ET AL.:

ASSOCIATION OF..
Living in households in the third, fourth and fifth household's income quintile was associated with better self-perceived health compared to those in households in the first income quintile, pointing out that those with the lowest income have poorer health, which has been confirmed in numerous previous studies, both in Croatia (Šućur \& Zrinščak, 2007) and abroad (Mackenbach et al., 2008; Bauer, Huber, Jenny, Müller, \& Hämmig, 2009).

As recorded in previous studies poor social support was associated with poor health (Niškanović \& Šiljak, 2015).

In contrast to socioeconomic factors, among lifestyle factors only alcohol consumption remained significantly associated with poor health in the multivariate model - alcohol abstinence was associated with poorer health compared to the consumption of alcohol. This was in line with the results of some previous studies (Green \& Polen, 2001; Perlman \& Bobak, 2008); however there are also studies with opposite results, which found that alcohol abstinence was associated with better self-perceived health (Janković et al., 2012; Bobak, Pikhart, Hertzman, Rose, \& Marmot, 1998; Girón, 2012). Inconsistent results were also recorded for the association of smoking with poor health - some of the studies showed smoking to be associated with poor health (Girón, 2012; Ho, Lam, Fielding, \& Janus, 2003), while others showed it to be associated with better self-perceived health (Janković et al., 2012; Bobak et al., 1998) or not associated with self-perceived health at all (Wolk \& Rössner, 1996). A possible reason why alcohol consumption and smoking were found to be related to better self-perceived health in some studies, which is also true for alcohol consumption in this study, could be in the thesis that healthy people are more often alcohol consumers and smokers compared to the people who are ill, which could not be evaluated in this study due to its limitation of being a cross-sectional study. Related to these results, it is important to mention that smoking and drinking rates in Croatia are high compared to the rest of Europe. Namely, according to Health for All Database, pure alcohol consumption, measured in litres per capita for individuals aged 15 years and older, in Croatia was 12.14 in 2014, which puts Croatia among countries with the highest pure alcohol consumption in Europe (World Health Organisation, 2018). Data for smoking rates are similar; according to Eurostat, in 2014 in Croatia, 24.5\% of individuals aged 15 years and older were daily smokers of cigarettes, which is significantly higher than the average for the EU countries (18.4\%) (Eurostat, 2018). Regarding daily smokers of tobacco products, Croatia is, with $25 \%$ of daily smokers, again in the top six countries of EU (Eurostat, 2018). This could lead to a relatively high percentage of persons who quit alco- 
DRUŠ. ISTRAŽ. ZAGREB GOD. 28 (2019), BR. 2, STR. 229-248

IVIČEVIĆ UHERNIK, A. ET AL.:

ASSOCIATION OF... hol drinking as well as smoking due to illness among non-smokers and non-drinkers, thus contributing to the observed association of alcohol abstinence with poor self-perceived health in both the univariate and multivariate models and association of non-smoking with poor self-perceived health in the univariate model.

The fact that this study is cross-sectional means also that only the association between poor health and demographic, socioeconomic and lifestyle factors could be analysed, without any conclusions concerning their temporal relations, which also led to limitations in establishing a possible causality. Further limitations of this study include possibly insufficient precision of both self-perceived health as a measure of health as well as lifestyle factors, whose more detailed breakdown might have given further insight into their association with poor self-perceived health. Self-perceived health, despite being recognised and evaluated as an important health indicator is prone to a certain degree of subjectivity and this should be taken into account when using the results of this study. Another limitation of this study is that it does not consider other heterogeneities i.e. ethnicity and other, while the exploration of these connections is beyond the scope of the study. These results also do not resolve the question concerning the relative importance of subjective and objective socioeconomic status as the causes of health inequalities - this study is focused on measuring the magnitude of its effects on self-perceived health.

However, despite its limitations, this study provides an important insight into the association of socioeconomic factors with health in Croatia. This is the first study done in the Croatian population which explored the association of lifestyle factors (such as smoking, alcohol consumption, body mass index and fruits and vegetables intake) with self-perceived health, alongside demographic and socioeconomic factors. Indicators of lifestyle factors are quite unfavourable in the Croatian population with a high percentage of smokers, alcohol consumers and those with increased body mass index, which points out the importance of analysing their association with self-perceived health.

The results of this study enable comparisons with previous studies on self-perceived health of the Croatian population and a follow-up on the trends. They also suggest that the association of socioeconomic factors with health in Croatia is not mediated exclusively through lifestyle factors, but also through other factors which were not included in this study and are probably more difficult to measure, but remain a possible target for further research. 
DRUŠ. ISTRAŽ. ZAGREB GOD. 28 (2019), BR. 2, STR. 229-248

IVIČEVIĆ UHERNIK, A. ET AL.:

ASSOCIATION OF..
The obtained results can be used in the planning of health and social policies as they emphasise that socioeconomic factors are independently associated with self-perceived health (not exclusively through lifestyle factors), meaning that efforts to improve self-perceived health in the Croatian population cannot be directed exclusively to lifestyle factors improvement.

Babić-Banaszak, A., Kovačić, L., \& Mastilica, M. (2002). What the citizens of Croatia think about their health. Acta Medica Croatica, 56(4-5), 145-150.

Bauer, G. F., Huber, C. A., Jenny, G. J., Müller, F., \& Hämmig, O. (2009). Socioeconomic status, working conditions and self-rated health in Switzerland: Explaining the gradient in men and women. International Journal of Public Health, 54(1), 23-30. https://doi.org/10.1007/s00038008-7077-2

Bobak, M., Pikhart, H., Hertzman, C., Rose, R., \& Marmot, M. (1998). Socioeconomic factors, perceived control and self-reported health in Russia. A cross-sectional survey. Social Science \& Medicine, 47(2), 269 279. https://doi.org/10.1016/S0277-9536(98)00095-1

Bonner, W. I. A., Weiler, R., Orisatoki, R., Lu, X., Andkhoie, M., Ramsay, D., Yaghoubi, M., Steeves, M., Szafron, M., \& Farag, M. (2017). Determinants of self-perceived health for Canadians aged 40 and older and policy implications. International Journal for Equity in Health, 16(1), 94. https://doi.org/10.1186/s12939-017-0595-x

Crimmins, E. M., Jung Ki, K., \& Solé-Auró, A. (2011). Gender differences in health: Results from SHARE, ELSA and HRS. European Journal of Public Health, 21(1), 81-91. https://doi.org/10.1093/eurpub/ckq022

Croatian Institute of Public Health (2016). European Health Interview Survey (EHIS) in Croatia 2014-2015. Basic Indicators. Zagreb.

Darviri, C., Artemiadis, A. K., Tigani, X., \& Alexopoulos, E. C. (2011). Lifestyle and self-rated health: A cross-sectional study of 3,601 citizens of Athens, Greece. BMC Public Health, 11, 619. https://doi.org/10.1186/ 1471-2458-11-619

Džakula, A., Babić Bosanac, S., Brborović, O., Vukušić Rukavina, T., \& Vončina L. (2007). Association of social roles, health, and health behavior of elderly women in Croatia. Croatian Medical Journal, 48(5), 684-690.

European Commission (2017a). European Core Health Indicators (ECHI). Available at https://ec.europa.eu/health/indicators/echi_en

European Commission (2017b). Degree of urbanisation. Available at http://ec.europa.eu/nat/web/degree-of-urbanisation

Eurostat (2017). Self-perceived health statistics. Available at http://ec.europa. eu/eurostat/statistics-explained/index.php/Self-perceived_health_ statistics

Eurostat (2018). Tobacco consumption. Available at https://ec.europa.eu/ eurostat/data/database

Franzini, L., \& Fernandez-Esquer, M. E. (2006). The association of subjective social status and health in low-income Mexican-origin in- 
DRUŠ. ISTRAŽ. ZAGREB GOD. 28 (2019), BR. 2, STR. 229-248

IVIČEVIĆ UHERNIK, A. ET AL.:

ASSOCIATION OF... dividuals in Texas. Social Science \& Medicine, 63(3), 788-804. https://doi. org/10.1016/j.socscimed.2006.01.009

Girón, P. (2012). Determinants of self-rated health in Spain: Differences by age groups for adults. European Journal of Public Health, 22(1), 36-40. https://doi.org/10.1093/eurpub/ckq133

Green, C. A., \& Polen, M. R. (2001). The health and health behaviors of people who do not drink alcohol. American Journal of Preventive Medicine, 21(4), 298-305. https://doi.org/10.1016/S0749-3797(01)00365-8

Ho, S. Y., Lam, T. H., Fielding, R., \& Janus, E. D. (2003). Smoking and perceived health in Hong Kong Chinese. Social Science $\mathcal{E}$ Medicine, 57(9), 1761-1770. https://doi.org/10.1016/S0277-9536(03)00021-2

Hu, P. F., Adler, N. E., Goldman, N., Weinstein, M., \& Seeman, T. E. (2005). Relationship between subjective social status and measures of health in older Taiwanese persons. Journal of the American Geriatrics Society, 53(3), 483-488. https://doi.org/10.1111/j.1532-5415.2005.53169.x

Janković, J., Janević, T., \& Von dem Knesebeck, O. (2012). Socioeconomic inequalities, health damaging behavior, and self-perceived health in Serbia: A cross-sectional study. Croatian Medical Journal, 53(3), 254-262. https://doi.org/10.3325/cmj.2012.53.254

Janković, J., \& Simić, S. (2012). The association of demographic and socioeconomic determinants and self-perceived health. Serbian Archives of Medicine, 140(1-2), 77-83. https://doi.org/10.2298/SARH1202077J

Jerez-Roig, J., Souza, D. L., Andrade, F. L., Lima Filho, B. F., Medeiros R. J., Oliveira, N. P., Cabral Neto, S. M., \& Lima, K. C. (2016). Self-perceived health in institutionalized elderly. Ciência $\mathcal{E}$ Saúde Coletiva, 21(11), 3367-3375. https://doi.org/10.1590/1413-812320152111.15562015

Jureša, V., Ivanković, D., Vuletić, G., Babić-Banaszak, A., Srček, I., Mastilica, M., \& Budak, A. (2000). The Croatian Health Survey - SF-36: I. General Quality of Life Assessment. Collegium Antropologicum, 24(1), 69-78.

Kraja, F., Kraja, B., Cakerri, L., \& Burazeri, G. (2016). Socio-demographic and lifestyle correlates of self-perceived health status in a population-based sample of Albanian adult men and women. Materia Socio Medica, 28(3), 173-177. https://doi.org/10.5455/msm.2016.28.173-177

Kurtinová, O. (2015). Self-perceived health in the Czech population: Recent evidence. Central European Journal of Public Health, 23(1), 45-53. https://doi.org/10.21101/cejph.a3996

Mackenbach, J. P., Stirbu, I., Roskam, A. J. R., Schaap, M. M., Menvielle, G., Leinsalu, M., Kunst, A. E., \& European Union Working Group on Socioeconomic Inequalities in Health (2008). Socioeconomic inequalities in health in 22 European countries. The New England Journal of Medicine, 358(23), 2468-2481. https://doi.org/10.1056/ NEJMsa0707519

McFadden, D. (1974). Conditional logit analysis of qualitative choice behavior. In P. Zarembka (Ed.), Frontiers in econometrics (pp. 105-142). New York: Academic Press.

McFadden, D. (1979). Quantitative methods for analyzing travel behaviour on individuals: Some recent developments. In D. Hensher, \& P. Stopher (Eds.), Behavioural travel modelling (pp. 279-318). London: Croom Helm London. 
DRUŠ. ISTRAŽ. ZAGREB GOD. 28 (2019), BR. 2, STR. 229-248

IVIČEVIĆ UHERNIK, A. ET AL.:

ASSOCIATION OF.
Meltzer, H. (2003). Development of a common instrument for mental health. In A. Nosikov \& C. Gudex (Eds.), EUROHIS: Developing Common Instruments for Health Surveys. Amsterdam: IOS Press.

Menec, V. H., \& Nowicki, S. (2014). Examining the relationship between communities' 'age-friendliness' and life satisfaction and self-perceived health in rural Manitoba, Canada. Rural and Remote Health, 14, 2594.

Niškanović, J., \& Šiljak, S. (2015). Social support, self-perceived health and mental status of general population of Republic of Srpska. Serbian Archives of Medicine, 143(3-4), 180-185.

Novak, D., Suzuki, E., \& Kawachi, I. (2015). Are family, neighbourhood and school social capital associated with higher self-rated health among Croatian high school students? A population-based study. BMJ Open, 5(6). https://doi.org/10.1136/bmjopen-2014-007184

Ostrove, J. M., Feldman, P., \& Adler, N. E. (1999). Relations among socioeconomic status indicators and health for African-Americans and Whites. Journal of Health Psychology, 4(4), 451-463. https://doi.org/ $10.1177 / 135910539900400401$

Perlman, F., \& Bobak, M. (2008). Determinants of self-rated health and mortality in Russia - are they the same? International Journal for Equity in Health, 7(1), 19. https://doi.org/10.1186/1475-9276-7-19

Pickett, W., King, N., Trask, C., Michaelson, V., Marlenga, B. L., Hagel, L., Dosman, J. A., Pickett, W., Dosman, J., Hagel, L., Brison, R., Day, A., Lawson, J., Trask, C., Marlenga, B., Day, L., Koehncke, N., \& Voaklander, D. C. (2015). Factors related to self-perceived health in rural men and women. Journal of Agromedicine, 20(2), 178-187. https://doi.org/10.1080/ 1059924X.2015.1010063

Simon, J. G., De Boer, J. B., Joung, I. M. A., Bosma, H., \& Mackenbach, J. P. (2005). How is your health in general? A qualitative study on self-assessed health. European Journal of Public Health, 15(2), 200-208. https://doi.org/10.1093/eurpub/cki102

Singh-Manoux, A., Marmot, M. G., \& Adler, N. E. (2005). Does subjective social status predict health and change in health status better than objective status? Psychosomatic Medicine, 67(6), 855-861. https://doi. org/10.1097/01.psy.0000188434.52941.a0

Smolić, Š. (2017). The determinants of health among the population aged 50 and over: Evidence from Croatia. Public Sector Economics, 41(1), 85-108. https://doi.org/10.3326/pse.41.1.9

Steptoe, A., \& Wardle, J. (2017). Life skills, wealth, health, and wellbeing in later life. Proceedings of the National Academy of Sciences, 114(17), 4354-4359. https://doi.org/10.1073/pnas.1616011114

Šućur, Z., \& Zrinščak, S. (2007). Differences that hurt: Self-perceived health inequalities in Croatia and European Union. Croatian Medical Journal, 48(5), 653-666.

Vuletić, G. (2013). Samoprocijenjeno zdravlje i kvaliteta života u Bjelovarsko-bilogorskoj županiji: regionalne razlike i specifičnosti (Self-perceived health status and quality of life in the Bjelovar-Bilogora county - Regional differences and specificities). Radovi Zavoda za znanstvenoistraživački i umjetnički rad u Bjelovaru, (7), 213-222. 
DRUŠ. ISTRAŽ. ZAGREB GOD. 28 (2019), BR. 2, STR. 229-248

IVIČEVIĆ UHERNIK, A. ET AL.:

ASSOCIATION OF..
Wolk, A., \& Rössner, S. (1996). Obesity and self-perceived health in Sweden. International Journal of Obesity and Related Metabolic Disorders, 20(4), 369-372.

World Health Organisation (2005). Healthy Diet. Fact sheet 394. Available at http://www.who.int/mediacentre/factsheets/fs394/en/

World Health Organisation (2018). Health for All database. Available at https://gateway.euro.who.int/en/datasets/european-health-for-alldatabase/

\section{Povezanost samoprocijenjenoga lošeg zdravlia s demografskim i socio- ekonomskim čimbenicima te životnim stilom među odraslom populacijom u Hrvatskoj}

Ana IVIČEVIĆ UHERNIK

Hrvatski zavod za javno zdravstvo, Zagreb

Dunja SKOKO-POLJAK

Ministarstvo zdravstva Republike Hrvatske, Zagreb

Vlasta DEČKOVIĆ-VUKRES

Hrvatski zavod za javno zdravstvo, Zagreb

Melita JELAVIĆ

Nastavni zavod za javno zdravstvo "Dr. Andrija Štampar", Zagreb

Sandra MIHEL, Tomislav BENJAK, Vesna ŠTEFANČIĆ,

Želika DRAUŠNIK, Ranko STEVANOVIĆ

Hrvatski zavod za javno zdravstvo, Zagreb

Cilj je ovog rada bio analizirati povezanost samoprocijenjenoga lošeg zdravlja s demografskim i socioekonomskim čimbenicima te životnim stilom na temelju podataka iz Europske zdravstvene ankete. Prilikom primiene modela multiple logističke regresije dva demografska (muškarci, starija dob), sva četiri socioekonomska (niska razina obrazovanja, nezaposleni i umirovljeni, osobe koje žive u kućanstvima s najnižim dohotkom, slaba socijalna podrška) i jedan čimbenik životnoga stila (osobe koje ne piju alkohol) prepoznati su kao povezani sa samoprocijenjenim lošim zdravljem. Povezanost socioekonomskih čimbenika sa samoprocjenom zdravlia među odraslom populacijom u Hrvatskoj izravna je i nije posredovana isključivo kroz životni stil.

Ključne riječi: samoprocjena zdravlja, Europska zdravstvena anketa, socioekonomski čimbenici, životni stil

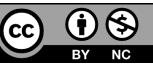

Međunarodna licenca / International License: 